\title{
COVID-19 Severity and Serum Level of Procalcitonin: A Systematic Review
}

\author{
Mohamed Awny Abdelhamid Abouhemda* \\ Mabarat El Maadi Hospital, El Maadi, Cairo, Egypt \\ *Corresponding Author: Mohamed Awny Abdelhamid Abouhemda, Mabarat El \\ Maadi Hospital, El Maadi, Cairo, Egypt.
}

Received: November 29, 2021

Published: December 23, 2021

(C) All rights are reserved by Mohamed Awny

Abdelhamid Abouhemda.

\section{Abstract}

Objective: To review the serum level of procalcitonin in relation to COVID-19 severity.

Data Sources: All articles published between 2003 and 2021 were subjected to a comprehensive search of MEDLINE (PubMed, Medscape, Science Direct, EMF-Portal) and the Internet.

Study Selection: English-language reports of procalcitonin and COVID-19 were chosen for this study. The initial search yielded 127 articles, 51 of which met the requirements for inclusion.

Data Extraction: Articles that did not include procalcitonin or COVID-19 in the title or abstract were excluded from the study. Data on methodology was collected by 26 independent investigators.

Data Synthesis: Structured reviews were used to make comparisons, with the results tallied. COVID-19 mortality-related risk factors have been studied in 21 studies, while PCT level has been studied in 30 studies in relation to COVID-19 severity.

Findings: As of 2020, Egypt's total number of COVID-19 patients is predicted to be in the range of 710-5241 patients. Dyspnea, diabetes mellitus, lymphopenia, elevated CRP, ESR, ferritin, ALT, AST, low albumin, increased D-dimer, and the presence of CT chest abnormalities might all be used as predictors for COVID-19 severity. Most prior investigations discovered a statistically highly significant relationship between serum procalcitonin levels and COVID-19 severity (p0.001).

Conclusion: Demographic, clinical, haematological, biochemical, and imaging data, as well as dyspnea, diabetes mellitus, obesity, smoking, lymphopenia, elevated CRP, ESR, ferritin, ALT, AST, low albumin, increased D-dimer, and the presence of CT chest findings, were found to be predictors of COVID-19 severity in this study. These aspects should be given extra attention, and more evaluations should be done to look into the underlying processes of these effects. PCT may also serve as a predictor of disease severity and aid in identifying the severity of COVID-19 patients. Serial PCT measurements may also be helpful in predicting prognosis. Additional research is needed to better understand the methods by which more PCT is produced and released in SARSCoV-2 patients.

Keywords: Covid-19; Procalcitonin; Mortality Risk; Egyptian Patients; Severity Disease

\section{Introduction}

Coronavirus disease 2019 (COVID-19), which is caused by infection with the severe acute respiratory syndrome coronavirus 2 (SARS-CoV-2), has quickly spread over more than 200 nations, areas, or territories [1]. SARS-CoV-2 is a novel positive-sense RNA virus with 79 percent homology to SARS-CoV and 50 percent homology to Middle East respiratory syndrome coronavirus (MERS-
CoV), but it is significantly more infectious than either. COVID-19 had been confirmed in a total of 5103006 people as of May 24, 2020, resulting in 333401 deaths. COVID-19 has spread over the globe [2].

Fever, cough, dyspnea, shortness of breath, and exhaustion are among the most prevalent symptoms of COVID-19. According to the findings, the causal culprit is coronavirus 2 (severe acute respira- 
tory syndrome) (SARS-CoV-2). Pneumonia with acute respiratory distress syndrome, septic shock, and associated sequelae are the most common clinical symptoms [3]. However, there are no specific symptoms to diagnose coronavirus infection, and reliable diagnosis relies on reverse transcription-polymerase chain reaction (RTPCR) analysis to detect the viral genome [4].

Egypt is a country in Africa, located in the northeast corner of the continent, with a population of around 100 million people and a land area of $1,010,408 \mathrm{~km}^{2}$. It is surrounded on the north by the Mediterranean Sea, on the east by the Red Sea, on the west by Libya, and on the south by Sudan. The Egyptian Constitution declares health to be a fundamental human right. On January 26, 2020, Egypt was banning all flights from China to Egypt. The first confirmed case of a Chinese individual in Egypt was officially declared on February 14, 2020. A quarantine station has been established for the patient. The Egyptian cabinet formally denied any proven Egyptian cases on February 28, 2020. The second COVID-19 case was formally revealed on March 1, 2020, [5].

The first Egyptian case of COVID-19 death was reported on March 20, 2020, twenty days after the first case of COVID-19 death in Egypt (for a German person). Since the $7^{\text {th }}$ of March through the $21^{\text {st }}$ of March, all schools/universities and mosques have been closed [5]. The Egyptian government has instituted various sorts of lockdowns in order to mitigate the epidemic's impact. Many eventualities are possible, as the COVID-19 epidemic could fade away in the spring or summer, or it could turn into the world's greatest pandemic. During the COVID-19 pandemic, healthcare professionals are at a high risk of becoming infected. To overcome shortages of medical supplies and personnel, the majority of Egyptian hospitals have been equipped to deal with COVID-19 patients [5].

Insights into disease pathophysiology are developing, as are ways to quickly detect and assess COVID-19 infection. Biomarkers in the lab are less expensive, faster, and easier to get. As a result, they have been the favoured method of monitoring and predicting illness outcomes and prognosis. Understanding the variance and profile of individual biomarkers as a function of different COVID-19 outcomes would aid in the creation of a risk stratified strategy to the care of COVID-19 patients. When compared to milder cases in which survival is the outcome, studies have shown that severe or fatal cases of COVID-19 disease are associated with an elevated white cell count, blood urea nitrogen, creatinine, markers of liver and kidney function, $\mathrm{C}$ reactive protein (CRP), interleukin-6 (IL-6), lower lymphocyte $(1000 / \mathrm{L})$ and platelet counts $\left(100 \times 10^{9} / \mathrm{L}\right)$, as well as albumin levels [6].

The 116-amino-acid precursor of the hormone calcitonin is procalcitonin (PCT). Patients hospitalised for moderate or severe forms of coronavirus disease-19 (COVID-19) usually have elevated serum procalcitonin (PCT) [7]. The presence of circulating endotoxins is the primary trigger for PCT production. As a result, PCT is commonly used as a biomarker for systemic bacterial infections in clinical practise, and has been interpreted as a signal of secondary bacterial infection in COVID-19 [8].

Increases in proinflammatory cytokines such as interleukin-6 (IL-6), interleukin-1b (IL-1b), and tumour necrosis factor- (TNF-) can also promote PCT production [9]. These mediators are heavily implicated in the so-called cytokine storm, which is defined by the emergence of respiratory symptoms and interstitial lung infiltrates on chest radiography as COVID-19 progresses from the viremic to the hyperinflammatory stage. Thus, PCT elevation may represent a direct consequence of the COVID-19 cytokine storm and could also be interpreted in the framework of a viral sepsis syndrome [10].

PCT elevation has been identified as a predictive indicator of unfavourable outcomes in COVID-19, including progression from moderate to severe and critical forms of the disease, ICU hospitalisation, mechanical ventilation, and mortality, according to several systematic reviews and meta-analyses [11]. Many additional inflammatory indicators, including as IL-6, C-reactive protein (CRP), D-dimer, and WBC increase, have similar predictive role with PCT [12].

As a result, the goal of this study was to examine the blood level of procalcitonin in relation to the severity of COVID-19.

\section{Materials and Methods}

\section{Data sources}

A thorough investigation of Severe COVID-19 and procalcitonin levels in the blood All studies published between 2003 and 2021 were analyzed using MEDLINE (PubMed, Medscape, Science Direct, EMF-Portal) and the Internet. Mortality-related risk factors/ COVID-19 severity/procalcitonin level/COVID-19 severity I and procalcitonin levels were studied during the investigation. From 2003 to 2021, the search was conducted in electronic databases. 


\section{Study selection}

Articles that met the criteria were peer-reviewed and authored in English. COVID-19 and procalcitonin were not mentioned in the title or abstract of any articles. Original studies, systematic reviews, or meta-analyses were evaluated, and final inclusion decisions were made based on the following criteria: primary or first-line treatment and, if necessary, subsequent treatment were documented, as well as treatment success, complications, and side effects.

\section{Data extraction}

COVID-19 and procalcitonin were not mentioned in the title or abstract of any articles. Data on methodology, health outcomes, and traditional protocol was retrieved by 25 independent investigators. Letters/comments/editorials/news, and studies not centred on COVID-19 and procalcitonin. In addition to the Evidence Pyramid, the analyzed papers were appraised according to evidence-based medicine (EBM) criteria using the US Preventive Services Task Force categorization and UK National Health Service methodology for EBM [13].

U.S. Preventive Services Task Force [13].

- Level I: Evidence obtained from at least one properly designed randomized controlled trial.

- Level II-1: Evidence obtained from well-designed controlled trials without randomization.

- Level II-2: Evidence obtained from well-designed cohort or case-control analytic studies, preferably from more than one center or research group.

- Level II-3: Evidence obtained from multiple time series with or without the intervention. Dramatic results in uncontrolled trials might also be regarded as this type of evidence.

- Level III: Opinions of respected authorities, based on clinical experience, descriptive studies, or reports of expert committees.

\section{Study quality assessment}

All the studies were judged on their quality. Study design, ethical approval, evidentiary power calculation, established eligibility criteria, proper controls, adequate information, and specified evaluation instruments were all important elements. Confounding factors were expected to be recorded and managed for, as well as adequate data analysis and an explanation for missing data.
Data synthesis

The results of a structured systematic review were tabulated. COVID-19 mortality-related risk factors have been studied in 21 studies, while PCT level has been studied in 30 studies in relation to COVID-19 severity (Figure 1).

\section{Results}

\section{Study selection and characteristics}

A thorough investigation of Severe COVID-19 and procalcitonin levels in the blood All studies published between 2003 and 2021 were analyzed using MEDLINE (PubMed, Medscape, Science Direct, EMF-Portal) and the Internet. Articles with titles or abstracts that did not include COVID-19 mortality-related risk variables or PCT level in relation to COVID-19 severity were excluded. Data on methodology, health outcomes, and traditional protocol was collected by 26 independent investigators. A total of 50 articles were identified as potentially relevant, but they were omitted because they did not meet our inclusion criteria. Because 54 studies met the inclusion criteria, they were reviewed. COVID-19 mortality-related risk factors have been studied in 21 studies, while PCT level has been studied in 30 studies in relation to COVID-19 severity (Figure $1)$.

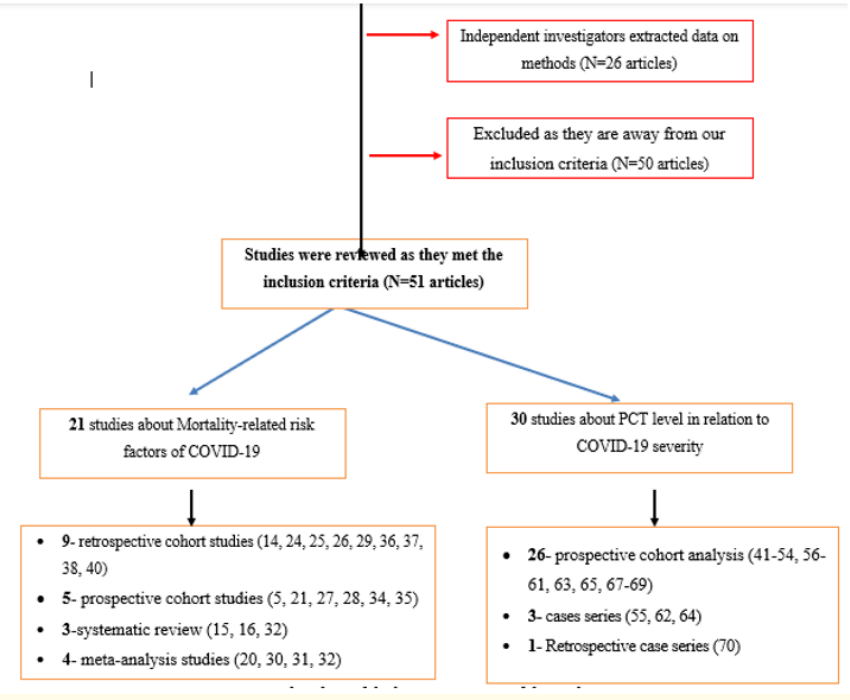

Figure 1. Flowchart of the literature review of the studies.

There were nine retrospective cohort studies [14,24-26,29,36$38,40]$ that were classified as level II-2 or (level B) and suggested that the estimated total number of COVID-19 patients in Egypt as 
of March 31 might be between 710 and 5241 individuals. Dyspnea, diabetes mellitus, obesity, smoking, lymphopenia, elevated CRP, ESR, ferritin, ALT, AST, low albumin, increased D-dimer, and the presence of CT chest abnormalities might all be used as predictors for COVID-19 severity.

In addition, five prospective cohort studies [5,21-28,34], all of which were classified as level II-2, found that the nations listed do not have the same spread or mortality curves, stages of the epidemic, or management procedures. Hospitalization and fatality rates are lower in females with coronavirus than in males. Patients with
COPD, hypertension, diabetes, CVD, and cancer had a significant impact on COVID-19 patients. The combined OR and HR showed a significant positive relationship between acute renal damage and COVID-19 mortality. While three systematic evaluations [15,16,32] found that old age was strongly related with MERS-Cov and SARS mortality, they did not reach Level III. Furthermore, four metaanalysis studies $(20,30,31,39)$ have been classified as Level III or (level c), indicating that greater age is associated with an increased risk of mortality from coronavirus, as measured by the pooled OR and HR. Diabetes is a factor in COVID-19 patient severity and mortality (Table 1).

\begin{tabular}{|c|c|c|c|c|}
\hline Author & Year & $\begin{array}{l}\text { Study } \\
\text { design }\end{array}$ & $\begin{array}{l}\text { Level of } \\
\text { EBM }\end{array}$ & Results \\
\hline Hassany., et al. [14] & 2020 & $\begin{array}{l}\text { Retrospective } \\
\text { study }\end{array}$ & Level II-2 & $\begin{array}{l}\text { The expected total number of patients with COVID-19 in Egypt, as of } \\
\text { March 31, could be in the range of 710-5241 patients. }\end{array}$ \\
\hline $\begin{array}{l}\text { Saba and Elsheikh, } \\
\text { [5] }\end{array}$ & 2020 & $\begin{array}{l}\text { Prospective } \\
\text { cohort }\end{array}$ & Level II-2 & $\begin{array}{l}\text { The listed countries do not share the same curves of spread or deaths, } \\
\text { stages of the epidemic, or steps of interventions. }\end{array}$ \\
\hline $\begin{array}{l}\text { Hong., et al. }[15] \\
\text { Choi., et al. }[16]\end{array}$ & $\begin{array}{l}2018 \\
2003\end{array}$ & $\begin{array}{l}\text { Systematic } \\
\text { review }\end{array}$ & Level III & Old age was significantly associated with MERS-Cov and SARS mortality. \\
\hline Abate., et al. [20] & 2020 & Meta-analysis & Level III & $\begin{array}{l}\text { Older age has shown increased risk of mortality due to coronavirus and } \\
\text { the pooled OR and HR. }\end{array}$ \\
\hline Scully., et al. [21] & 2020 & $\begin{array}{c}\text { Prospective } \\
\text { cohort }\end{array}$ & Level II-2 & $\begin{array}{l}\text { Female with coronavirus have lower rates of hospitalization and } \\
\text { mortality than male. }\end{array}$ \\
\hline Zhou., et al. [24] & 2020 & $\begin{array}{l}\text { Retrospective } \\
\text { cohort study }\end{array}$ & Level II-2 & $\begin{array}{l}\text { Coronavirus related risk of mortality was significantly associated with } \\
\text { smoker patients when compared to non-smoker patients. }\end{array}$ \\
\hline $\begin{array}{l}\text { Van Gerwen ., et al. } \\
\text { [25] Soares., et al. } \\
{[26]}\end{array}$ & $\begin{array}{l}2021 \\
2020\end{array}$ & $\begin{array}{l}\text { Retrospective } \\
\text { cohort study }\end{array}$ & Leve & Significant association between obesity and coronaviruses mortality. \\
\hline $\begin{array}{l}\text { Dessie and } \\
\text { Zewotir [27] }\end{array}$ & $\begin{array}{l}2021 \\
2020\end{array}$ & $\begin{array}{l}\text { Prospective } \\
\text { cohort }\end{array}$ & Level II-2 & $\begin{array}{l}\text { Mortality among hospitalized COVID-19 patients with diabetes was } \\
\text { higher compared to the patients without diabetes and HR }\end{array}$ \\
\hline Fang., et al. [28] & 2020 & $\begin{array}{l}\text { Prospective } \\
\text { cohort }\end{array}$ & Lev & $\begin{array}{l}\text { COVID-19 patients are highly influenced by patients with COPD, } \\
\text { hypertension, CVD and cancer. Diabetes also contributes to more severe } \\
\text { COVID-19 and higher rates of mortality. }\end{array}$ \\
\hline Ghweil., et al. [29] & 2020 & $\begin{array}{l}\text { Retrospective } \\
\text { study }\end{array}$ & Level II-2 & $\begin{array}{l}\text { Demographic, clinical, hematological, biochemical, and imaging data, } \\
\text { dyspnea, diabetes mellitus, lymphopenia, raised CRP, ESR, ferritin, ALT, } \\
\text { AST, low albumin, and presence of CT chest findings could be considered } \\
\text { as predictors for COVID-19 severity. }\end{array}$ \\
\hline $\begin{array}{l}\text { Fadini., et al. [30], } \\
\text { Wang., et al. }[31]\end{array}$ & $\begin{array}{l}2020 \\
2020\end{array}$ & Meta & Level III & diabetes is a determinant of severity and mortality of COVID-19 patient. \\
\hline Alqahtani., et al. [32] & 2020 & $\begin{array}{l}\text { Systematic } \\
\text { review }\end{array}$ & Level III & $\begin{array}{l}\text { COPD patients with COVID-19 showed higher rates of hospitalization } \\
\text { and mortality. }\end{array}$ \\
\hline $\begin{array}{l}\text { Klang., et al. [34], } \\
\text { and } \\
\text { Hernández-Galda- } \\
\text { mez., et al. [35] }\end{array}$ & $\begin{array}{l}2020 \\
2020\end{array}$ & $\begin{array}{l}\text { Prospective } \\
\text { cohort }\end{array}$ & Level II-2 & $\begin{array}{l}\text { A significant positive association between acute kidney injury and } \\
\text { COVID-19 mortality and the pooled OR and HR. }\end{array}$ \\
\hline $\begin{array}{l}\text { Mikami., et al. [36], } \\
\text { Chilimuri., et al. [37], } \\
\text { Wu., et al. [38] }\end{array}$ & $\begin{array}{l}2021 \\
2020\end{array}$ & $\begin{array}{l}\text { Retrospective } \\
\text { cohort study }\end{array}$ & Level II-2 & $\begin{array}{l}\text { A significant association between increase D-dimer and coronaviruses } \\
\text { mortality. }\end{array}$ \\
\hline Shah., et al. [39] & 2020 & meta-analysis & Level III & A high level of D-dimer increases severe infection and risk of mortality. \\
\hline Zhou., et al. [40] & 2020 & $\begin{array}{l}\text { Retrospective } \\
\text { cohort study }\end{array}$ & Level II-2 & $\begin{array}{l}\text { Rising D-dimer levels during hospitalization are associated with the } \\
\text { worst long-term outcomes. }\end{array}$ \\
\hline
\end{tabular}

Table 1: Mortality-related risk factors of COVID-19 $(n=21)$. 
Regarding PCT levels and COVID-19 severity, 26 prospective cohort analyses [41-54,56-61,63,65,67-69] found a statistically significant relationship between serum procalcitonin levels and COVID-19 severity, with the best cut-off values for elevated PCT being $>0.5,>0.1,>0.04,>0.24,>0.05$, and > $0.25(\mathrm{ng} / \mathrm{mL})$. In addition, three case series $[55,62,64]$ were classified as Level III or (level C), with the optimum cut-off values for raised PCT being $>0.5$ and $>$ $0.9(\mathrm{ng} / \mathrm{mL})$, respectively, with significant levels of $\mathrm{p}>0.001$. While one retrospective case series [70] that reached level $\mathrm{C}$ found that the optimum cut-off values for elevated PCT were $>0.5(\mathrm{ng} / \mathrm{mL})$, with $\mathrm{p}>0.001$ levels of significance (Table 2).

\begin{tabular}{|c|c|c|c|c|c|c|}
\hline Author & $\begin{array}{c}\text { Year of } \\
\text { recruitment } \\
\text { initiation }\end{array}$ & Region & Study design & $\begin{array}{l}\text { Cut-off used } \\
\text { for elevated } \\
\text { PCT }(\mathrm{ng} / \mathrm{mL})\end{array}$ & $\begin{array}{c}\text { PCT correlation } \\
\text { with severity (p } \\
\text { value }=\text { correlation } \\
\text { coefficient) }\end{array}$ & Level of EBM \\
\hline Bhandari., et al. [41] & 2020 & Indian & $\begin{array}{l}\text { Prospective } \\
\text { cohort }\end{array}$ & $\mathrm{N} / \mathrm{R}$ & $\begin{array}{l}\text { PCT elevated in all } \\
\text { severe cases }\end{array}$ & Level II-2 \\
\hline Cecconi., et al. [42] & 2020 & Italy & $\begin{array}{l}\text { Prospective } \\
\text { cohort }\end{array}$ & $>0.5$ & $\mathrm{p}<0.001$ & Level II-2 \\
\hline Cen., et al. [43] & 2020 & China & $\begin{array}{c}\text { Prospective } \\
\text { cohort }\end{array}$ & $>0.5$ & $P=0.044$ & Level II-2 \\
\hline Chen., et al. [44] & 2020 & China & $\begin{array}{l}\text { Prospective } \\
\text { cohort }\end{array}$ & $>0.5$ & $\mathrm{p}<0.001$ & Level II-2 \\
\hline Chen., et al. [45] & 2019 & China & $\begin{array}{l}\text { Prospective } \\
\text { cohort }\end{array}$ & $>0.5$ & $\mathrm{p}<0.001$ & Level II-2 \\
\hline Chen., et al. [46] & 2020 & China & $\begin{array}{c}\text { Prospective } \\
\text { cohort }\end{array}$ & $>1.0$ & $\mathrm{P}=0.044$ & Level II-2 \\
\hline Chen., et al. [47] & 2020 & China & $\begin{array}{l}\text { Prospective } \\
\text { cohort }\end{array}$ & $>0.5$ & $\mathrm{p}<0.001$ & Level II-2 \\
\hline Duan., et al. [48] & 2020 & China & $\begin{array}{l}\text { Prospective } \\
\text { cohort }\end{array}$ & $>0.04$ & $\mathrm{p}<0.001$ & Level II-2 \\
\hline Gavin., et al. [49] & 2020 & USA & $\begin{array}{l}\text { Prospective } \\
\text { cohort }\end{array}$ & $>0.24$ & $\mathrm{p}<0.00004$ & Level II-2 \\
\hline Gregoriano., et al. [50] & 2020 & $\begin{array}{c}\text { Swit- } \\
\text { zerland }\end{array}$ & $\begin{array}{c}\text { Prospective } \\
\text { cohort }\end{array}$ & $>0.05$ & $\mathrm{p}<0.0002$ & Level II-2 \\
\hline Guo., et al. [51] & 2020 & China & $\begin{array}{c}\text { Prospective } \\
\text { cohort }\end{array}$ & $>0.04$ & $\mathrm{p}<0.001$ & Level II-2 \\
\hline Hon., et al. [52] & 2020 & China & $\begin{array}{c}\text { Prospective } \\
\text { cohort }\end{array}$ & $\mathrm{N} / \mathrm{R}$ & $\mathrm{p}<0.004$ & Level II-2 \\
\hline Hou., et al. [53] & 2020 & China & $\begin{array}{c}\text { Prospective } \\
\text { cohort }\end{array}$ & $\mathrm{N} / \mathrm{R}$ & $\mathrm{p}<0.001$ & Level II-2 \\
\hline Hu., et al. [54] & 2020 & China & $\begin{array}{c}\text { Prospective } \\
\text { cohort }\end{array}$ & $>0.05$ & $\mathrm{p}<0.055$ & Level II-2 \\
\hline Ke., et al. [55] & 2020 & China & Case series & $>0.05$ & $\begin{array}{c}\text { PCT was elevated in } \\
\text { all cases }\end{array}$ & Level III \\
\hline Li., et al. [56] & 2020 & China & $\begin{array}{l}\text { Prospective } \\
\text { cohort }\end{array}$ & $>0.05$ & $\begin{array}{c}\text { PCT had no sig- } \\
\text { nificant changes in } \\
\text { association disease } \\
\text { severity }\end{array}$ & Level II-2 \\
\hline
\end{tabular}




\begin{tabular}{|c|c|c|c|c|c|c|}
\hline Li., et al. [57] & 2020 & China & $\begin{array}{l}\text { Prospective } \\
\text { cohort }\end{array}$ & $>0.5$ & $\begin{array}{l}\text { PCT was elevated in } \\
10.67 \% \text { of patients }\end{array}$ & Level II-2 \\
\hline Lima., et al. [58] & 2020 & USA & $\begin{array}{l}\text { Prospective } \\
\text { cohort }\end{array}$ & $>0.5$ & $\begin{array}{c}\text { PCT was elevated in } \\
\text { two cases }\end{array}$ & Level II-2 \\
\hline McRae., et al. [59] & 2020 & USA & $\begin{array}{l}\text { Prospective } \\
\text { cohort }\end{array}$ & $>0.05$ & $\mathrm{p}<0.001$ & Level II-2 \\
\hline $\begin{array}{l}\text { Ortiz-Brizuela., et al. } \\
{[60]}\end{array}$ & 2020 & Mexico & $\begin{array}{l}\text { Prospective } \\
\text { cohort }\end{array}$ & $>0.05$ & $\mathrm{p}<0.001$ & Level II-2 \\
\hline $\begin{array}{l}\text { Price-Haywood., et } \\
\text { al. [61] }\end{array}$ & 2020 & USA & $\begin{array}{l}\text { Prospective } \\
\text { cohort }\end{array}$ & $>0.25$ & $\begin{array}{c}\text { Elevated PCT } \\
\text { associated with in- } \\
\text { hospital mortality } \\
\text { HR }\end{array}$ & Level II-2 \\
\hline Rastrelli., et al. [62] & 2020 & Italy & Case series & $>0.09$ & $\mathrm{p}<0.001$ & Level III \\
\hline Rath., et al. [63] & 2020 & $\begin{array}{l}\text { Ger- } \\
\text { many }\end{array}$ & $\begin{array}{c}\text { Prospective } \\
\text { cohort }\end{array}$ & $\mathrm{N} / \mathrm{R}$ & $\mathrm{p}<0.002$ & Level II-2 \\
\hline Sattar., et al. [64] & 2020 & USA & Case report & $\mathrm{N} / \mathrm{R}$ & $\begin{array}{l}\text { PCT levels in- } \\
\text { creased with dis- } \\
\text { ease progression }\end{array}$ & Level III \\
\hline Shao., et al. [65] & 2020 & China & $\begin{array}{l}\text { Prospective } \\
\text { cohort }\end{array}$ & $>0.05$ & $P=0.032$ & Level II-2 \\
\hline Zaninotto., et al. [66] & 2020 & Italy & $\begin{array}{l}\text { Prospective } \\
\text { cohort }\end{array}$ & $>0.5$ & $\begin{array}{c}\text { PCT was elevated in } \\
2 \text { severe cases }\end{array}$ & Level II-2 \\
\hline Zeng., et al. [67] & 2020 & China & $\begin{array}{c}\text { Prospective } \\
\text { cohort }\end{array}$ & $>0.5$ & $\mathrm{p}<0.001$ & Level II-2 \\
\hline Zhang., et al. [68] & 2020 & China & $\begin{array}{c}\text { Prospective } \\
\text { cohort }\end{array}$ & $>0.5$ & $\mathrm{p}<0.003$ & Level II-2 \\
\hline Zhang., et al. [69] & 2020 & China & $\begin{array}{l}\text { Retrospective } \\
\text { case series }\end{array}$ & $>0.5$ & $\mathrm{p}<0.001$ & Level III \\
\hline Zhang., et al. [70] & 2019 & China & $\begin{array}{c}\text { Prospective } \\
\text { cohort }\end{array}$ & $>0.01$ & $\mathrm{p}<0.004$ & Level II-2 \\
\hline
\end{tabular}

Table 2: PCT level in relation to COVID-19 severity $(n=31)$.

\section{Discussion}

Egypt reported 710 COVID-19 cases and 46 deaths as of March 31 (fatality rate: 648 percent, 95 percent confidence interval: 478855). It accepts that, in the absence of open screening, the overall number of patients may be underestimated and the fatality rate may be overestimated. To assess the expected disease burden in Egypt, fatality rates from the United States and Germany, which used open screening, as well as regional nations with similar conditions to Egypt, were used (Algeria, Bahrain, Iran, Israel, Jordan, Saudi Arabia, Lebanon, Morocco, Palestine, Qatar, Tunisia, Turkey, and United Arab Emirates). The mortality rate of all reported na- tions ranged from $07 \%$ to $118 \%$, according to a WHO report released on March 31 [14]. Authors calculated a factor by dividing our fatality rate by the global rate and the rates of the listed countries. This multiplier was then multiplied by the number of cases we had found to arrive at an estimate the expected total number.

As of March 31, the overall number of COVID-19 patients in Egypt was estimated to be between 710 and 5241. Notably, excluding patients who did not contract the virus in the reporting nation may have reduced these figures. Furthermore, the mentioned countries do not have the same spread or fatality curves, stages of the epidemic, or intervention methods [5]. MERS-Cov [15] and 
SARS [16] mortality were found to be substantially linked to old age. Some age-related chronic medical disorders and/or a reduced immune level could be a viable explanation [17]. Furthermore, the functions of CD4+T cells, CD8+T cells, and B cells are also affected by age [18]. In the meta-analysis [19], older age was associated with an increased risk of coronavirus-related mortality, as measured by the pooled OR and HR. The pooled OR and HR of Alqahtani., et al. [20] showed a considerably greater risk. Females with coronavirus have lower hospitalisation and fatality rates than males with the virus [21]. When compared to women, men have fewer CD8+T cells, CD4+T cells, and reduced B cell generation in the adaptive immune system [22]. Furthermore, because some essential immune regulatory genes are found on the $\mathrm{X}$ chromosome, women patients may benefit from greater TLR7 expression [23]. When comparing smokers to non-smokers, smokers had a muchincreased risk of dying from the Coronavirus [24]. Furthermore, Van Gerwen., et al. [25], as well as Soares., et al. [26] found a link between obesity and coronavirus mortality. Dessie and Zewotir [27] found that mortality was greater among COVID-19 hospitalised patients with diabetes than among those without diabetes and HR. Patients with COPD, hypertension, CVD, and cancer, on the other hand, have a significant impact on the risk of mortality among hospitalised COVID-19 patients. Diabetes also leads to a worsening of COVID-19 and increased mortality rates [28]. Dyspnea, diabetes mellitus, lymphopenia, elevated CRP, ESR, ferritin, ALT, AST, low albumin, and the presence of CT chest abnormalities were all found to be predictors of COVID-19 severity by Ghweil., et al. [29] among the investigated demographic, clinical, haematological, biochemical, and imaging data.

Diabetes is also a factor of severity and mortality in COVID-19 patients, according to two small systematic reviews [30,31]. Alqahtani., et al. [32] also claimed that COPD patients with COVID-19 had higher hospitalisation and mortality rates. This could be because viral infections in COPD patients cause systemic inflammation, which causes symptoms to take longer to heal [33]. There was a strong positive connection between acute renal damage and COVID-19 mortality and the pooled OR and HR, according to Klang., et al. [34] and Hernández-Galdame., et al. [35] Furthermore, Mikami., et al. [36], Chilimuri., et al. [37], and Wu., et al. [38] discovered a link between D-dimer levels and coronavirus mortality. A previous study (39) shown that a high level of D-dimer increased the risk of serious illness and fatality. Rising D-dimer levels during hospitali- sation have been linked to the worst long-term results, according to Zhou., et al. [40].

The need of laboratory evaluation and early prediction of the severity of a patient's illness has been highlighted because of the global medical catastrophe caused by the COVID-19 pandemic. A robust and reliable relationship between serum PCT level and severity prediction of viral etiologies has been frequently reported since its introduction on the diagnostic platform in 1993 [41]. The extrathyroidal secretion of PCT is assumed to be significantly increased during viral infections and, furthermore, actively precipitated by inflammatory cytokines in the context of COVID-19 [4255].

Several studies have found a strong correlation between PCT and severity or significantly higher PCT levels in the severe patient's group, indicating that PCT is a viable predictive biomarker. However, Li., et al. found no significant link between PCT and prognosis in COVID-19 cases, which could be owing to a limited fraction of critically sick $(n=5)$ and expired $(n=11)$ cases, or the results could be different if a larger cohort is studied. [56] A few research offered clinical and outcome profiles of COVID-19 cases in their respective setups, with varying proportions of severe cases, although the majority of studies lacked homogeneity when it came to biochemical parameter evaluation, owing to frequently changing guidelines. Because interferon (INF)-upsurge is thought to limit PCT release, the PCT value should remain much lower than the optimum cut-off in conditions of noncritical or severe infection [57]. Similarly, the best cut-off in this study was $>0.05 \mathrm{ng} / \mathrm{mL}$, which was used by studies to classify severe cases and determine statistical relationship, i.e., 35 percent $(n=18)$.

More than $75 \%$ of the studies revealed were carried out on Chinese people. Because the expression of PCT is assumed to be dependent on the genetic architecture of the population, this could be a complicating issue [58]. However, a few studies included Caucasians and South Asians in this study, and comparable substantial associations between PCT and severity were found [59-62]. This multiethnic study backs up our claim that PCT can be used as a predictive biomarker in COVID-19 cases.

According to Liu., et al., PCT levels larger than $0.07 \mathrm{ng} / \mathrm{mL}$ with an AUC of 0.812 and sensitivity and specificity of 73.15 and 84.85 percent, respectively, can be used in routine clinical practise in 
conjunction with other biochemical markers and clinical picture for the prediction of morbidity [63-67]. Knowing which instances are likely to proceed to the severe stage can help with resource allocation and aggressive treatment programmes [68]. Most of the studies were inpatient-based, making longitudinal follow-up more feasible, which is critical for evaluating PCT's prognostic effectiveness. Furthermore, the population studied in this research was multiethnic, encompassing Chinese, Indians, Europeans, North and South Americans, and others. The exclusion of non-English periodicals, primarily from China, is one of the most prominent constraints [70].

\section{Conclusion}

Demographic, clinical, haematological, biochemical, and imaging data, as well as dyspnea, diabetes mellitus, obesity, smoking, lymphopenia, elevated CRP, ESR, ferritin, ALT, AST, low albumin, increased D-dimer, and the presence of CT chest findings, were found to be predictors of COVID-19 severity in this study. PCT may also serve as a predictor of disease severity and aid in identifying the severity of COVID-19 patients.

\section{Recommendations}

These aspects should be given extra attention, and more evaluations should be done to look into the underlying processes of these effects. Serial PCT measurements may also be helpful in predicting prognosis. Additional research is needed to better understand the methods by which more PCT is produced and released in SARSCoV-2 patients.

Bibliography

1. Wang D., et al. "Clinical characteristics of 138 hospitalized patients with 2019 novel coronavirus-infected pneumonia in Wuhan, China". JAMA 323.11 (2020): 1061-1069.

2. Hu R., et al. "Procalcitonin levels in COVID-19 patients". International Journal of Antimicrobial Agents 56.2 (2020): 106051.

3. Liu ZM., et al. "Association of procalcitonin levels with the progression and prognosis of hospitalized patients with COVID-19". International Journal of Medical Sciences 17.16 (2020): 2468.

4. Udugama B., et al. "Diagnosing COVID-19: the disease and tools for detection". ACS Nano 14.4 (2020): 3822-3835.

5. Saba AI and Elsheikh AH. "Forecasting the prevalence of COVID-19 outbreak in Egypt using nonlinear autoregressive artificial neural networks". Process Safety and Environmental Protection 141 (2020): 1-8.
6. Ruan Q., et al. "Clinical predictors of mortality due to COVID-19 based on an analysis of data of 150 patients from Wuhan, China". Intensive Care Medicine 46.5 (2020): 846-848.

7. Ponti G., et al. "Biomarkers associated with COVID-19 disease progression". Critical Reviews in Clinical Laboratory Sciences 57.6 (2020): 389-399.

8. Ticinesi A., et al. "The Clinical Significance of Procalcitonin Elevation in Patients over 75 Years Old Admitted for COVID-19 Pneumonia". Mediators of Inflammation (2021).

9. Fajgenbaum DC and June CH. "Cytokine storm". New England Journal of Medicine 383.23 (2020): 2255-2273.

10. Li H., et al. "SARS-CoV-2 and viral sepsis: observations and hypotheses". The Lancet 395.10235 (2020): 1517-1520.

11. Tjendra Y., et al. "Predicting disease severity and outcome in COVID-19 patients: a review of multiple biomarkers". Archives Of Pathology and Laboratory Medicine 144.12 (2020): 14651474.

12. Malik P., et al. "Biomarkers and outcomes of COVID-19 hospitalizations: systematic review and meta-analysis". BMJ Evidence-Based Medicine 26.3 (2021): 107-108.

13. Guirguis-Blake J., et al. "Current processes of the U.S. Preventive Services Task Force: refining evidence-based recommendation development". Annals of Internal Medicine 147.2 (2007): 117-122.

14. Hassany M., et al. "Estimation of COVID-19 burden in Egypt". The Lancet Infectious Diseases 20.8 (2020): 896-897.

15. Hong K-H., et al. "Predictors of mortality in Middle East respiratory syndrome (MERS)”. Thorax 73.3 (2018): 286-289.

16. Choi KW., et al. "Outcomes and prognostic factors in 267 patients with severe acute respiratory syndrome in Hong Kong". Annals of Internal Medicine 139.9 (2003): 715-723.

17. Wang K., et al. "Clinical and laboratory predictors of in-hospital mortality in 305 patients with COVID-19: a Cohort Study in Wuhan, China". China 71.16 (2020): 2079-2088.

18. Goronzy JJ and Weyand CM. "Successful and maladaptive T cell aging”. Immunity 46.3 (2017): 364-378.

19. Abate S., et al. "Prevalence and risk factors of mortality among hospitalized patients with COVID-19: a systematic review and Meta-analysis". Bull World Health Organ (2020). 
20. Alqahtani JS., et al. "Prevalence, severity and mortality associated with COPD and smoking in patients with COVID-19: a rapid systematic review and meta-analysis". PLOS ONE 15.5 (2020): e0233147.

21. Scully EP., et al. "Considering how biological sex impacts immune responses and COVID-19 outcomes". Nature Reviews Immunology 20 (2020): 442-447.

22. Abdullah M., et al. "Gender effect on in vitro lymphocyte subset levels of healthy individuals". Cell Immunology 272.2 (2012): 214-219.

23. Parohan M., et al. "Risk factors for mortality in patients with Coronavirus disease 2019 (COVID-19) infection: a systematic review and meta-analysis of observational studies". The Aging Male 23.5 (2020): 1416-1424.

24. Zhou F., et al. "Clinical course and risk factors for mortality of adult inpatients with COVID-19 in Wuhan, China: a retrospective cohort study". Lancet 395 (2020): 1054-1062.

25. Van Gerwen M., et al. "Risk factors and outcomes of COVID-19 in New York City; a retrospective cohort study". Journal of Medical Virology 93.2 (2021): 907-915.

26. Soares RdCM., et al. "Risk factors for hospitalization and mortality due to COVID-19 in Espírito Santo State, Brazil". American Journal of Tropical Medicine and Hygiene 103.3 (2020): 1184-1190.

27. Dessie and Zewotir BMC Infectious Disease 21 (2021): 855.

28. Fang L., et al. "Are patients with hypertension and diabetes mellitus at increased risk for COVID-19 infection?" The Lancet Respiratory Medicine 8.4 (2020): e21.

29. Ghweil AA., et al. "Characteristics, outcomes and indicators of severity for COVID-19 among sample of ESNA Quarantine Hospital's Patients, Egypt: a retrospective study". Infection and Drug Resistance 13 (2020): 2375.

30. Fadini G., et al. "Prevalence and impact of diabetes among people infected with SARS-CoV-2". Journal of Endocrinology Investigation 43.6 (2020): 867-869.

31. Wang B., et al. "Does comorbidity increase the risk of patients with COVID-19: evidence from meta-analysis". Aging (Albany NY) 12.7 (2020): 6049.

32. Alqahtani JS., et al. "Prevalence, severity and mortality associated with COPD and smoking in patients with COVID-19: a rapid systematic review and meta-analysis". PLOS ONE 15.5 (2020): e0233147.
33. Williams NP., et al. "Impact of radiologically stratified exacerbations: insights into pneumonia aetiology in COPD”. Respiratory Research 19.1 (2018): 143.

34. Klang E., et al. "Morbid obesity as an independent risk factor for COVID-19 mortality in hospitalized patients younger than 50". Obesity 28.9 (2020): 1595-1599.

35. Hernández-Galdamez DR., et al. "Increased risk of hospitalization and death in patients with COVID-19 and pre-existing noncommunicable diseases and modifiable risk factors". Archives of Medical Research 51.7 (2020): 683-689.

36. Mikami T., et al. "Risk factors for mortality in patients with COVID-19 in New York City". Journal of General Internal Medicine 36 (2021): 17-26.

37. Chilimuri S., et al. "Predictors of mortality in adults admitted with COVID-19: retrospective cohort study from New York City". Western Journal of Emergency Medicine 21.4 (2020): 779.

38. Wu C., et al. "Risk factors associated with acute respiratory distress syndrome and death in patients with coronavirus disease 2019 pneumonia in Wuhan, China". JAMA Internal Medicine 180.7 (2020): 934-943.

39. Shah S., et al. "Elevated D-dimer levels are associated with increased risk of mortality in COVID-19: a systematic review and meta-analysis". Cardiology in Review 28.6 (2020): 295-302.

40. Zhou F., et al. "Clinical course and risk factors for mortality of adult inpatients with COVID-19 in Wuhan, China: a retrospective cohort study". The Lancet 395 (2020): 1054-1062.

41. Bhandari S., et al. "Clinical profile of Covid-19 infected patients admitted in a tertiary care hospital in North India". Journal Associate of Physicians India 68.5 (2020): 13-17.

42. Cecconi M., et al. "Early predictors of clinical deterioration in a cohort of 239 patients hospitalized for Covid-19 infection in Lombardy, Italy". Journal of Clinical Medicine 9.5 (2020): 1548.

43. Cen Y., et al. "Risk factors for disease progression in patients with mild to moderate coronavirus disease 2019 - a multicentre observational study". Clinical Microbiology and Infection 26.9 (2020): 1242-1247.

44. Chen R., et al. "Risk factors of fatal outcome in hospitalized subjects with coronavirus disease 2019 from a nationwide analysis in china". Chest 158.1 (2020): 97-105.

45. Chen R., et al. "Longitudinal hematologic and immunologic variations associated with the progression of COVID-19 patients in China". The Journal of Allergy and Clinical Immunology 146.1 (2020): 89-100. 
46. Chen T., et al. "Clinical characteristics and outcomes of older patients with coronavirus disease 2019 (COVID-19) in Wuhan, China (2019): a single-centered, retrospective study". Journals of Gerontology Series A: Biological Sciences and Medical Sciences 75.9 (2020): 1788-1795.

47. Chen X., et al. "Differences between COVID-19 and suspected then confirmed SARS-CoV-2-negative pneumonia: a retrospective study from a single center". Journal of Medical Virology 92.9 (2020): 1572-1579.

48. Duan J., et al. "Correlation between the variables collected at admission and progression to severe cases during hospitalization among patients with COVID-19 in Chongqing". Journal of Medical Virology 11 (2020).

49. Gavin W., et al. "Clinical characteristics, outcomes and prognosticators in adult patients hospitalized with COVID-19". American Journal of Infection Control 42.9 (2020): 158-165.

50. Gregoriano C., et al. "Characteristics, predictors and outcomes among 99 patients hospitalized with COVID-19 in a tertiary care centre in Switzerland: an observational analysis". Swiss Medical Weekly150 (2020): w20316.

51. Guo T., et al. "Cardiovascular implications of fatal outcomes of patients with coronavirus disease 2019 (COVID-19)". JAMA Cardiology 5.7 (2020): 811-818.

52. Hong Y., et al. "Clinical characteristics of coronavirus disease 2019 and development of a prediction model for prolonged hospital length of stay". Annals of Translational Medicine 8.7 (2020): 443.

53. Hou H., et al. "Using IL-2R/lymphocytes for predicting the clinical progression of patients with COVID-19". Clinical EXperimental Immunology 201.1 (2020): 76-84.

54. Hu R., et al. "Procalcitonin levels in COVID-19 patients". International Journal of Antimicrobial Agents 2 (2020): 106051.

55. Ke C., et al. "2019 Novel coronavirus disease (COVID-19) in hemodialysis patients: a report of two cases". Clinical Biochemistry 81 (2020): 9-12.

56. Li H., et al. "Serum amyloid A is a biomarker of severe coronavirus disease and poor prognosis". Journal of Infection 80.6 (2020): 646-655.

57. Li R., et al. "Clinical characteristics of 225 patients with COVID-19 in a tertiary hospital near Wuhan, China". Journal of Clinical Virology 127 (2020): 104363.
58. Lima B., et al. "COVID-19 in recent heart transplant recipients: clinicopathologic features and early outcomes". Transplant Infectious Disease 5 (2020): 13382.

59. McRae MP., et al. "Clinical decision support tool and rapid point-of-care platform for determining disease severity in patients with COVID-19". Lab on a Chip 20.12 (2020): 20752085.

60. Ortiz-Brizuela E., et al. "Clinical and epidemiological characteristics of patients diagnosed with Covid-19 in a tertiary care center in Mexico City: a prospective cohort study". Revista de Investigación Clínica 72.3 (2020): 165-177.

61. Price-Haywood EG., et al. "Hospitalization and mortality among black patients and white patients with Covid-19". New England Journal of Medicine 382.26 (2020): 2534-2543.

62. Rastrelli G., et al. "Low testosterone levels predict clinical adverse outcomes in SARS-CoV-2 pneumonia patients". Andrology 9.1 (2020): 88-89.

63. Rath D., et al. "Impaired cardiac function is associated with mortality in patients with acute COVID-19 infection". Clinical Research Cardiology 109.12 (2020): 1491-1499.

64. Sattar Y., et al. "Coronavirus disease 2019 with acute respiratory distress syndrome mimicking heart failure exacerbation: time to rethink". Cardiology Research 11.3 (2020): 196-199.

65. Shao L., et al. "Novel insights into illness progression and risk profiles for mortality in non-survivors of COVID-19". Frontiers in Medicine (Lausanne) 7 (2020): 246.

66. Zaninotto M., et al. "Presepsin in risk stratification of SARSCoV-2 patients". Clinica Chimica Acta 507 (2020): 161-163.

67. Zeng Z., et al. "Simple nomogram based on initial laboratory data for predicting the probability of ICU transfer of COVID-19 patients: multicenter retrospective study". Journal of Medical Virology (2020).

68. Zhang B., et al. "Novel coronavirus disease 2019 (COVID-19): relationship between chest CT scores and laboratory parameters". European Journal of Nuclear Medicine and Molecular Imaging 47.9 (2020): 2083-2089.

69. Zhang G., et al. "Clinical features and short-term outcomes of 221 patients with COVID-19 in Wuhan, China". Journal of Clinical Virology 127 (2020): 104364. 
70. Zhang J., et al. "Clinical, radiological and laboratory characteristics and risk factors for severity and mortality of 289 hospitalized COVID-19 patients". Allergy 76.2 (2020): 533-550.

\section{Assets from publication with us}

- Prompt Acknowledgement after receiving the article

- Thorough Double blinded peer review

- Rapid Publication

- Issue of Publication Certificate

- High visibility of your Published work

Website: www.actascientific.com/

Submit Article: www.actascientific.com/submission.php

Email us: editor@actascientific.com

Contact us: +919182824667 